\title{
Notification of infectious diseases by junior doctors in accident and emergency departments
}

\author{
Ruth L Spedding, Mark G Jenkins, Seamus A O'Reilly
}

\begin{abstract}
Objective-To assess the knowledge about notifiable infectious diseases by accident and emergency (A\&E) senior house officers.

Methods-A telephone questionnaire of senior house officers was carried out over a one week period at the end of their six month attachment in A\&E departments in Northern Ireland.

Results-81 (91\%) of the senior house officers participated in the study; 23 (29\%) realised that the doctor diagnosing the notifiable disease had a statutory duty to notify that disease; nine (11\%) were aware there were three statutory lists in the United Kingdom. Knowledge about which infectious diseases require notification varied from $79 / 81$ (98\%) for meningococcal disease to $15 / 91(19 \%)$ for methicillin resistant $S$ aureus. Seventy nine $(98 \%)$ of the doctors thought that a poster displayed in the A\&E department would be helpful. There was no significant difference between duration of qualification and performance on the questionnaire ( $p=$ 0.2).

Conclusions-Despite varying experience, junior doctors in $A \& E$ do not know which infectious diseases are notifiable by statute. They felt that it would be helpful to have a poster in the A\&E department listing the notifiable diseases of that region. To encourage accurate reporting, interregional variation between the statutory lists should be abolished and replaced by one nationally agreed list.

(F Accid Emerg Med 1998;15:102-104)
\end{abstract}

Keywords: notification of infectious disease; junior doctors

Belfast City Hospital, Belfast, Northern Ireland, UK R L Spedding

Royal Victoria Hospital, Belfast, Northern Ireland, UK

M G Jenkins

S A O'Reilly

Correspondence to: $\mathrm{R}$ Spedding, Specialist Registrar, Altnagelvin Area Hospital, Glenshane Road, Londonderry BT47 1SB

Northern Ireland, UK.
"Over the past 20 or 30 years we have become complacent. Advances in medicine have meant we no longer fear the infectious diseases that once killed a majority of our people"

Dr L Moonie MP

Mr S Galbraith MP

Sunday Post; 19 January 1997

The recent outbreak of $E$ coli 0157 in Scotland has re-emphasised the lethal potential of infectious diseases. Infectious diseases require rapid diagnosis with early and accurate notification. ${ }^{12}$ Notification is complicated by the multiplicity of statutory lists (England and Wales, ${ }^{3}$ Scotland, ${ }^{4}$ Northern Ireland, ${ }^{5}$ and Irish Republic ${ }^{6}$ ). There are 24 infectious diseases common to all of the lists. However, each list contains slightly different notifiable diseases. (table 1).

Public health statistics rely on all doctors notifying infectious diseases. ${ }^{2}$ The aim of our study was to assess awareness about the notification of infectious diseases by junior doctors working in accident and emergency (A\&E) departments.

\section{Methods}

A telephone survey was performed over a seven day period. This included senior house officers working in all of the $\mathrm{A} \& \mathrm{E}$ departments in Northern Ireland. They were telephoned by the authors without prior warning. A questionnaire (fig 1) was read out verbatim and the answers recorded. Any doctor declining to take part was excluded. Doctors on annual or sick leave during the week of the survey were also excluded.

\section{Results}

There are 19 A\&E departments in Northern Ireland, of which three are specialised units (for ophthalmic problems, ear/nose/throat, and paediatrics). In the six months ending 31 January 1997, 89 senior house officers were employed in these departments. Eighty one $(91 \%)$ of these answered the questionnaire. Seven were on annual/sick leave and one doctor declined to participate.

Only nine $(11 \%)$ were aware there were three different statutory notification lists in the United Kingdom. Twenty one (26\%) thought there was only one list, but others suggested there were up to 25 lists.

The ability of the doctors to identify which diseases required notification varied from $79 / 81$ (98\%) for meningococcal disease to $15 / 81(19 \%)$ for methicillin resistant $S$ aureus (MRSA) (table 2).

There were 23 senior house officers (29\%) who were aware that the doctor diagnosing the infectious disease had a statutory duty to notify that disease. Of the other doctors, $37(46 \%)$ did not know whose responsibility it was, nine $(11 \%)$ would tell the nurse in charge, seven ( $9 \%)$ the infection control nurse, two $(2 \%)$ the $\mathrm{A} \& \mathrm{E}$ consultant, and two $(2 \%)$ would have informed the infectious diseases unit or the public health department.

There were 14 doctors (17\%) who did not know how to notify an infection. The official notification form would have been used by 13 $(16 \%)$ of the doctors, $15(19 \%)$ would have telephoned the public health department, five $(6 \%)$ would have written to the public health department, and $13(16 \%)$ would have used the infection control nurse. The remainder 
Table 1 Notification of infectious diseases

\begin{tabular}{|c|c|c|c|}
\hline Scotland & Northern Ireland & England and Wales & Irish Republic \\
\hline Anthrax & Anthrax & Anthrax & Anthrax \\
\hline Bacillary dysentery & Dysentery & Dysentery & Bacillary dysentery \\
\hline Chickenpox & Chickenpox & - & - \\
\hline Cholera & Cholera & Cholera & Cholera \\
\hline- & - & - & Creutzfeld-Jacob \\
\hline Continued fever & - & - & - \\
\hline Diphtheria & Diphtheria & Diphtheria & Diphtheria \\
\hline Erysipelas & - & - & - \\
\hline Food poisoning & Food poisoning $\mathbf{G E}<2$ years & Food poisoning $\mathbf{G E}<2$ years & Food poisoning \\
\hline & - & - & Infectious mononucleosis \\
\hline Legionellosis & Legionnaires & - & Legionnaires \\
\hline Leptospirosis & Leptospirosis & Leptospirosis & Leptospirosis \\
\hline Lyme disease & - & - & - \\
\hline Malaria & Malaria & Malaria & Malaria \\
\hline Measles & Measles & Measles & Measles \\
\hline - & - & - & Ornithosis \\
\hline Meningococcal disease & Meningococcal septicaemia & Meningococcal septicaemia & Meningococcal septicaemia \\
\hline - & Acute encephalitis & Acute encephalitis & Acute encephalitis \\
\hline - & Acute meningitis & Acute meningitis & Acute meningitis \\
\hline Mumps & Mumps & Mumps & Mumps \\
\hline - & - & Ophthalmia neonatorum & - \\
\hline Paratyphoid & Paratyphoid & Paratyphoid & Paratyphoid \\
\hline Plague & Plague & Plague & Plague \\
\hline Polio & Acute polio & Acute polio & Acute polio \\
\hline Puerperal fever & - & - & - \\
\hline Rabies & Rabies & Rabies & Rabies \\
\hline Relapsing fever & Relapsing fever & Relapsing fever & Relapsing fever \\
\hline Rubella & Rubella & Rubella & Rubella \\
\hline Scarlet fever & Scarlet fever & Scarlet fever & Scarlet fever \\
\hline Smallpox & Smallpox & Smallpox & Smallpox \\
\hline Tetanus & Tetanus & Tetanus & Tetanus \\
\hline Toxoplasmosis & - & - & - \\
\hline $\begin{array}{l}\text { TB, respiratory/ } \\
\text { non-respiratory }\end{array}$ & TB, pulmonary/non-pulmonary & TB & TB \\
\hline Typhoid & Typhoid & Typhoid & Typhoid \\
\hline Typhus & Typhus & Typhus & Typhus \\
\hline Viral haemorrhagic fevers & Viral haemorrhagic fevers & Viral haemorrhagic fevers & Viral haemorrhagic fevers \\
\hline Viral hepatitis & Hepatitis $A, B$, unspecified viral & Viral hepatitis A, B & Viral hepatitis, unspecified \\
\hline Whooping cough & Whooping cough & Whooping cough & Whooping cough \\
\hline - & Yellow fever & Yellow fever & Yellow fever \\
\hline
\end{tabular}

would have relied on the $A \& E$ or medical consultant, the general practitioner, the nurse in charge, the bacteriology department, the occupational health department, or the infectious disease unit to notify the disease.

Seventy nine senior house officers (98\%) thought a handout or poster in the $A \& E$ department would be useful for reference. The two doctors who felt that a handout or poster would not be useful performed poorly in the questionnaire.

Forty nine of the doctors (61\%) had been qualified for two or three years (range two to 24 years). There was no significant difference ( $p=0.2, \chi^{2}$ test) between the duration of qualification and performance in the questionnaire.

\section{Discussion}

Government health statistics rely on accurate notification of infectious diseases by doctors. This assumes that doctors, after making the diagnosis, know which infectious diseases need to be notified and how to go about the process.

Table 2 Doctors' knowledge of notifiable diseases

\begin{tabular}{lll}
\hline Disease & Correct, $n$ (\%) & Incorrect, $n$ (\%) \\
\hline MRSA & $15(19)$ & $64(80)$ \\
Chickenpox & $27(34)$ & $50(63)$ \\
Measles & $38(48)$ & $39(49)$ \\
Influenza & $61(76)$ & $15(19)$ \\
Glandular fever & $65(81)$ & $11(14)$ \\
Malaria & $69(86)$ & $10(13)$ \\
Food poisoning & $70(88)$ & $7(8)$ \\
Croup & $75(94)$ & $1(1)$ \\
Tuberculosis & $78(98)$ & $2(2)$ \\
Meningococcal disease & $79(99)$ & $1(1)$ \\
\hline
\end{tabular}

MRSA, methicillin resistant $S$ aureus.
Our survey showed the majority of doctors were unaware of the existence of different national lists and the list contents. They were also unsure of the practicalities of notification. This may well have resulted in underreporting of notifiable diseases from $A \& E$ departments. ${ }^{2}$

A vulnerable section of the population attending $A \& E$ departments is at increased risk of infectious diseases, including homeless people, travellers, and hostel dwellers. ${ }^{7}$ They either do not have a general practitioner or attend A\&E departments for all their health problems. ${ }^{7}$ We must ensure that infectious disease are rapidly identified, treated, notified, and then followed up. ${ }^{8}$ It is imperative that A\&E departments take responsibility when dealing with such patients. In the busy working environment they need a user friendly system for rapid and easy notification.

The spectrum of infectious diseases is changing. New diseases are appearing and old infectious diseases re-emerging. The resurgence of tuberculosis in association with HIV is well recognised. ${ }^{10}$ Other infections such as MRSA have become prominent since the last formal revision of the statutory list. ${ }^{11} 12$

Given that the junior workforce of $A \& E$ departments is mobile, it would seem sensible to have a single agreed list of up to date notifiable diseases for the United Kingdom (ideally encompassing the Irish Republic).

Most of the senior house officers surveyed felt that a poster displayed in the $\mathrm{A} \& \mathrm{E}$ department containing the list of notifiable diseases in that region would be helpful. 


\section{NOTIFICATION OF INFECTIOUS DISEASES (ID) BY A\&E JUNIOR DOCTORS}

NAME

HOSPITAL:

GRADE:

YEAR QUALIFIED:

\section{QUESTIONS}

1. WHO NOTIFIES ID IN YOUR DEPT?

CONSULTANT

NURSE IN CHARGE

INFECTION CONTROL NURSE

HOSPITAL ADMINISTRATION/CLERICAL STAFF

GENERAL PRACTITIONER

DON'T KNOW

OTHER

2. HOW MANY STATUTORY NATIONAL LISTS EXIST IN THE UK? .NO. 1234 OTHER

3. HOW MANY ID S DID YOU PERSONALLY NOTIFY IN THE LAST 6 MONTHS ?

\section{AT PRESENT WHICH OF THE FOLLOWING ARE NOTIFIABLE IDS}

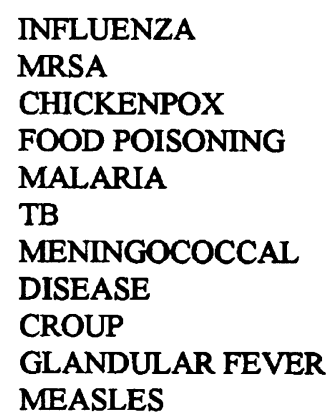

5. HOW WOULD YOU NOTIFY AN ID?

\section{WOULD A HANDOUT/POSTER IN YOUR DEPARTMENT HELP? YES / NO}

Figure 1 The questionnaire used in the survey.

\section{CONCLUSION}

Senior house officers in $A \& E$ departments are unsure which infectious diseases are notifiable. A reference poster displayed in the $A \& E$ department, listing the regional notifiable diseases, would be useful.

To further encourage accurate reporting, we suggest that the national variation between the statutory lists within the United Kingdom should be abolished and replaced by one updated list.

1 Killalea D, Ward LR, Roberts D, et al. International epidemiological and microbiological study of outbreak of Salmonella agona infection from a ready to eat savoury snack-I: England and Wales and the United States. BMJ 1996;313:1105-7.

2 Bryan RT, Pinner RW, Berkleman RL. Emerging infectious diseases in the United States: improved surveillance, arequisite for prevention. Ann NY Acad Sci 1994;740 346-61
3 Statutory Instruments (1988a). Public Health, England and Wales. The Public Health (Infectious Diseases) Regulation. (SI No 1546.) London: HMSO, 1988.

4 Statutory Instruments (1986). Public Health, Scotland. The Public Health Notification of Infectious Diseases (Scotland) Regulations. (SI No 1550.) London: HMSO, 1988

5 Statutory Rules (1990). Public Health Notifiable Diseases Order (Northern Ireland). (SR No 66.) Belfast: HMSO, 1990

6 Infectious Diseases Regulations. Dublin: Government Publication Office, 1981.

7 Barclay DM, Richardson JP, Fredman L. Tuberculosis in the homeless. Arch Fam Med 1995;4:541-6.

8 Kumar D, Citron KM, Leese J, Watson JM. Tuberculosis among the homeless at a temporary shelter in London: report of a chest X-ray screening programme. J Epidemiol Community Health 1995;49:629-33.

9 Sepkowitz KA, Raffalli J. Tuberculosis at the end of the twentieth century. Eur J Clin Microbiol Infect Dis twentieth century. Eur J Clin Microbiol Infect Dis 10 C

10 Croker R, Miller R. HIV associated tuberculosis. BMJ

11 Richardson J. Infection control. Keeping MRSA in perspective. Nursing Times 1996;92:58-60.

12 National surveillance for infectious diseases, 1995. MMWR 1995;44:737-9. 